\title{
Growth, survivorship, and habitat choice in a newly settled seagrass gastropod, Strombus gigas
}

\author{
Melody Ray, Allan W. Stoner \\ Caribbean Marine Research Center, 805 East 46th Place, Vero Beach, Florida 32963, USA
}

\begin{abstract}
The roles of nutrition, predation, and habitat choice were tested as mechanisms for shaping natural distribution of newly settled queen conch in seagrass Thalassia testudinum meadows in the central Bahamas. Small animals from 3 size classes were enclosed at 2 sites in 3 different habitats across a seagrass gradient (bare sand, low-density seagrass, medium-density seagrass) for 3 wk. Medium (11 $\mathrm{mm}$ shell length) and large $(22 \mathrm{~mm}$ ) newly settled conch grew faster in both seagrass habitats than on bare sand, but differences were not significant for small $(5 \mathrm{~mm})$ conch. Small and medium conch grown on sand, however, weighed more than those of the same length grown in seagrass. In laboratory habitat-choice experiments, newly settled conch preferred living seagrass and seagrass detritus over bare sand. Medium conch tethered in the 3 habitats at both sites suffered very high mortality (50 to $96 \%$ killed in $11 \mathrm{~d}$ ), with those tethered in medium-density seagrass showing an advantage. Juvenile conch over 1 yr old are primarily associated with medium-density seagrass, but younger animals have been observed on sand. Results from this study show that nutrition is adequate on sand for newly settled conch, but an ontogenetic shift from sand into seagrass is unlikely because predation occurs before food becomes limiting or a habitat choice can be made. Nevertheless, post-settlement mortality is high regardless of where conch settle in the seagrass gradient, and predation is the most important mechanism influencing distribution.
\end{abstract}

KEY WORDS: Strombus gigas - Bahamas - Habitat complexity · Habitat choice $\cdot$ Predation - Seagrass Tethering

\section{INTRODUCTION}

Seagrass meadows provide shelter and food for the young of many vertebrate and invertebrate species. and their significant role as nursery habitat is well known (Stoner 1983, Livingston 1984, Bell et al. 1988, Heck et al. 1989, Howard et al. 1989). Several important, closely related mechanisms influence animal distribution patterns within seagrass, including predation, nutrition, and habitat choice (Orth 1992). Prey species decrease their risk of predation by seeking shelter in the vegetative structure seagrass provides (e.g. Heck \& Thoman 1981, Heck \& Wilson 1987, Wilson et al. 1990, Smith \& Herrnkind 1992, Irlandi 1994), and some freshwater fishes apparently trade relatively high food resources for the safer conditions of vegetated areas (Werner \& Hall 1988, Petterson \& Bronmark 1993). Although Bell \& Westoby (1986) argue that active habitat choice, not predation, is the proximate cause for observed distribution of seagrass invertebrates, predation may ultimately drive the choice behavior (see also Woodbury 1986, Edgar \& Robertson 1992, Wahle \& Steneck 1992). Relative importance of these 2 mechanisms may vary among species (Leber 1985).

The queen conch Strombus gigas is a large, herbivorous marine gastropod commonly found in seagrass meadows of the Caribbean region. Certain ecological aspects of the species suggest the importance of such mechanisms as predation, nutrition, and habitat choice in determining distribution patterns. S. gigas exhibits habitat preference behavior in settlement (Davis \& Stoner 1994), juvenile, and adult stages (Weil \& Laughlin 1984, Stoner \& Waite 1990, Stoner \& Sandt 1992), suffers very high predation-induced mortality as a juvenile (Iversen et al. 1986, Appeldoorn 1988, Marshall 1992, Ray et al. 1994), exhibits differential growth across the seagrass gradient (Ray \& Stoner 1994), and 
may undergo an ontogenetic shift in habitat (Sandt \& Stoner 1993). Juveniles over 1 yr old are primarily associated with medium-density seagrass, though they do occur on sand and in low-density seagrass (Stoner \& Waite 1990). Despite much study of the species, conch $<55 \mathrm{~mm}$ shell length are rarely observed and very little is known about the earliest post-settlement stages. Factors affecting distribution patterns of newly settled conch obviously influence patterns of more conspicuous, older juveniles. In this study we tested the potential roles of nutrition, predation, and habitat choice on distribution of newly settled conch across a seagrass gradient using enclosures, tethers, and pairwise preference experiments.

\section{MATERIAL AND METHODS}

Study area. The Exuma Cays island chain comprises more than 100 cays and rocks that extend northwest to southeast in the central Bahamas, dividing Exuma Sound to the east from the Great Bahama Bank to the west (Fig. 1). Water exchange occurs through numerous tidal inlets that separate the islands, creating extensive flow fields on the bank. Most reproductive activity occurs in the sound on the island shelf where adults live in the highest densities (Stoner \& Schwarte 1994). Larvae are carried through the tidal passes and settle onto the bank (Stoner et al. 1994). Juveniles are not conspicuous until several months later, when they have grown to $60 \mathrm{~mm}$ in shell length (apex to siphonal canal). Discrete nursery aggregations occur in the same general locations year after year (Wicklund et al. 1991, Stoner et al. 1995a) and vary greatly in size, covering surface areas up to 600 ha. Most are located within $5 \mathrm{~km}$ of inlets on the bank side near sand bars in medium-density seagrass Thalassia testudinum (Stoner et al. 1994), and densities of 0.1 to 1.3 juveniles $\mathrm{m}^{-2}$ are common (Stoner \& Ray 1993).

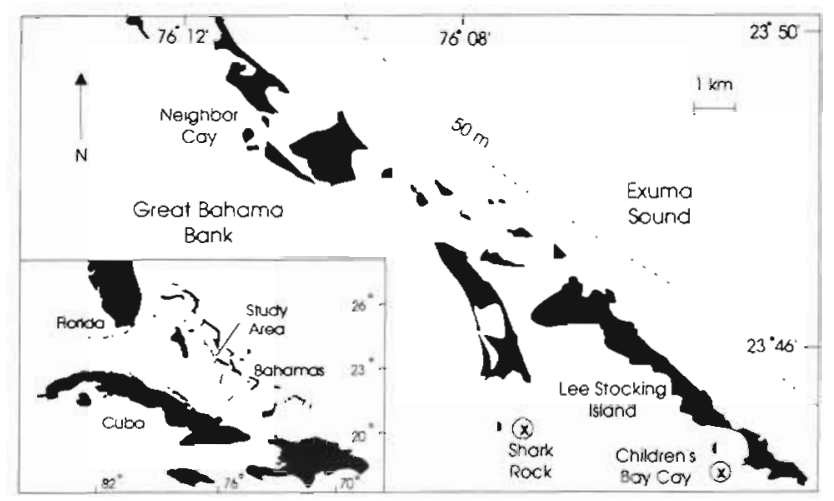

Fig. 1. Study sites Shark Rock and Children's Bay Cay in the Exuma Cays, central Bahamas
Two typical nurseries were selected as study sites, Shark Rock (SR) and Children's Bay Cay (CBC) (Fig. 1). Both have been the subject of intensive study; and, conch density, size distribution, and movement patterns, as well as environmental characteristics, have been described for them in detail (Stoner \& Waite 1990, Stoner \& Ray 1993, Stoner et al. 1994).

Methods. Enclosure and tether experiments were conducted in 3 different habitats (bare sand, low-density seagrass, and medium-density seagrass) at SR and $C B C$ to test habitat effects on growth rate and survivorship of newly settled conch ( $<25 \mathrm{~mm}$ shell length). Thalassia testudinum was the dominant seagrass and the only species quantified in this study. Halodule wrightii and Syringodium filiforme were present, but quantities were very low $\left(<2 \mathrm{~g}\right.$ dry $\left.w \mathrm{t} \mathrm{m}^{-2}\right)$. Habitats within both locations were selected for seagrass uniformity and presence of wild juvenile conch. Juveniles $1 \mathrm{yr}$ old and older (>90 mm) were abundant at both sites, ranging from 0 to 0.38 conch $\mathrm{m}^{-2}$ at $\mathrm{SR}$ and from 0.18 to 0.51 at $\mathrm{CBC}$, with highest densities in medium seagrass

Habitat-choice experiments were conducted in the laboratory on Lee Stocking Island, Bahamas (Fig, 1). All experimental conch were hatchery-reared and purchased from the Caicos Conch Farm in the Turks and Caicos Islands, West Indies; transit time to our laboratory was less than $15 \mathrm{~h}$. After arrival, animals were fed and allowed to acclimate on flow-through wet tables for at least $24 \mathrm{~h}$ prior to experimental use.

Growth experiment. Daily field growth rates were determined for 3 size classes of newly settled conch enclosed in cages for $3 \mathrm{wk}$. All conch were measured for shell length before enclosure. Small conch ranged in size from 4.5 to $5.5 \mathrm{~mm}[5.1 \pm 0.01$ (mean $\pm \mathrm{SD}$ ) at $\mathrm{CBC}, 5.0 \pm 0.02$ at $\mathrm{SR}]$ and were $\sim 5 \mathrm{wk}$ old, post-settlement. Medium conch ranged from 9.5 to $12.5 \mathrm{~mm}(11.3$ \pm 0.21 at $\mathrm{CBC}, 10.9 \pm 0.04$ at SRl and were 2 to $3 \mathrm{mo}$ old. Large conch ranged in size from 20.3 to $23.6 \mathrm{~mm}$ $(21.5 \pm 0.04$ at $\mathrm{CBC}, 21.7 \pm 0.15$ at SR) and were 4 to 5 mo old. Mean initial lengths within size class among the 3 habitats at each site were not significantly different from each other ( 1 -way ANOVA, $p>0.05$ in all 6 cases). For each size class, 5 replicate enclosures were used within each habitat at each site. Positions for enclosures were selected for equality in seagrass characteristics. Depth (at mean low water) ranged from 1.3 to $2.2 \mathrm{~m}$ at $\mathrm{SR}$ and 0.7 to $3.3 \mathrm{~m}$ at $\mathrm{CBC}$ across the seagrass gradient from bare sand to medium-density seagrass.

Cages for small conch were pvc cylinders (diameter $16 \mathrm{~cm}$, height $25 \mathrm{~cm}$, area $0.02 \mathrm{~m}^{2}$ ) with 21 large holes (diameter $5.5 \mathrm{~cm}$ ) cut from each to allow for water circulation. A close-fitting, tubular lining made of polyester (1 mm mesh) was inserted into each cylinder, 
stretched, folded over each end, and held securely with cable ties fastened around the top and bottom. Cages for medium and large conch were made of black plastic-coated wire (mesh $2.2 \mathrm{~cm} \times 4.7 \mathrm{~cm}$, diameter $30.5 \mathrm{~cm}$, height $25 \mathrm{~cm}$, area $0.073 \mathrm{~m}^{2}$ ). Polyester liners were inserted and fastened around the top and bottom as described for the pvc cages. All enclosures were pushed at least $3 \mathrm{~cm}$ into the substrate and secured to reinforcement bars driven into the sediment. Strips of aluminum sheet metal were pushed into the sediment around cages in sand and low-density seagrass habitats to prevent effects of tidal scouring.

Twenty small conch were enclosed in each pvc cage and 8 medium conch were enclosed in each wire cage from 16 June to 9 July 1993. Predators were removed from cages as possible without disturbing the substrate. An additional medium conch cage and another small conch cage were put out to replace cages from which conch loss was suspected during the first $5 \mathrm{~d}$ of the experiment. Large conch ( 8 per wire cage) were enclosed 11 to 31 August 1993.

When conch were recovered from the enclosures, one sediment sample (upper $2 \mathrm{~cm}$ ) was collected from inside each cage and from 6 haphazardly selected points outside the cages to characterize sediments for each habitat and to test for cage effects. All samples were dried at $80^{\circ} \mathrm{C}$ for $-24 \mathrm{~h}$ to constant weight. Subsamples $(10$ to $20 \mathrm{~g})$ from all samples were incinerated at $550^{\circ} \mathrm{C}$ for $4 \mathrm{~h}$ to determine organic content. To determine grain size and sorting, subsamples from representative samples inside and outside cages were also analysed using standard dry sieve procedures (Folk 1966). Product-moment statistics were generated according to McBride (1971).

After collection of sediment samples, all above-substrate macrophytes were picked from each enclosure and put into $1 \mathrm{~mm}$ mesh bags. Samples were separated to species in the laboratory. Thalassia testudinum was further separated into living biomass and detrital biomass. All samples were dried at $80^{\circ} \mathrm{C}$ for $\sim 24 \mathrm{~h}$ and weighed.

All live conch were measured for shell length, blotted, and wet weighed. At least $60 \%$ of the small conch were recovered from each cage (except 1 cage which was excluded from data analysis). At least $75 \%$ of the medium-sized conch were recovered from each cage (except 3 cages in which only $38 \%$ remained). All conch were recovered from 23 of the 30 large conch cages, with at least $50 \%$ recovery from the rest.

Daily growth rates were calculated using the mean initial and final shell length of conch from each cage. To test for differences in growth rate among habitats at each site, 1- and 2-way ANOVAs were performed followed by Tukey HSD multiple comparison test. ANOVAs were performed according to the guidelines of Day \& Quinn (1989) on data which were tested for homogeneity of variance (Cochran's test, p > 0.05); transformations were made as noted.

The relationship between final shell length and total weight was considered as an animal condition indicator in addition to growth rate. Because of the narrow range in length, linear regression with untransformed data provided the best fitting model. Analysis of covariance (ANCOVA) was performed to test for differences among the 3 habitats at each site, followed by pairwise comparisons. Because detritus is an important conch food (Stoner \& Waite 1991), growth was also analysed as a function of detrital biomass using linear regression.

Tether experiment. Medium-sized conch were tethered by blotting the shell dry and gluing the looped end of monofilament line $(1 \mathrm{~kg}$ test, finished length $\sim 25 \mathrm{~cm}$ ) around the shell spire with a cyanoacrylate ester adhesive (Duro Super-Glue Gel). The other end of the line was attached to a tagged stainless steel welding rod that was pushed into the substrate. Twenty $(-10 \mathrm{~mm})$ conch were glued in this manner and kept on a wet table for $17 \mathrm{~d}$ in August. Only 1 animal died, confirming that tethering methods were not lethal. Furthermore, lines remained securely attached to shells for 2 mo during constant immersion in sea water, and conch escape in the field was highly unlikely

On 12 August 1993, 5 blocks of tethered conch were transplanted to the 3 habitats where conch were enclosed at SR and CBC. Each block comprised 10 conch which were arranged in 2 rows and spaced $0.5 \mathrm{~m}$ apart. Blocks were at least $3 \mathrm{~m}$ apart. The experiment was terminated 7 September, after $26 \mathrm{~d}$.

Initial conch shell length ranged from 9.3 to $12.5 \mathrm{~mm}$ $(11.0 \pm 0.8)$. Differences among mean initial lengths were not significant among habitats at either site [1way ANOVA: (SR) $F_{(2,147)}=2.813, p=0.063 ;(\mathrm{CBC})$ $\left.F_{(2,146)}=0.173, \mathrm{p}=0.841\right]$.

To quantify seagrass characteristics in each habitat, the number of Thalassia testudinum shoots was counted in 5 quadrats $(25 \times 25 \mathrm{~cm}), 1$ near each block. Also, all above-substrate macrophytes and detritus in each quadrat were collected into bags and processed as described for the growth experiment.

To test for differences among habitats at each site, cumulative proportional mortality data were transformed (arcsine-square root), and 1-way ANOVA was performed followed by Tukey HSD multiple comparison test. Shell condition of each killed conch was noted in an attempt to ascertain predator identity. 'Shell gone' indicates the conch was removed completely from its tether and considered killed. Some conch, still attached to tethers, were found in stomachs of seastar Astropecten duplicatus. Damaged shells were grouped 
into 3 categories in order of damage severity. 'Aperture damage' indicates shells which were chipped along the aperture or were missing a chunk from the aperture. 'Peeled' conch were those whose apertures were heavily damaged along the whorl of spines. 'Crushed' conch were those for which only small pieces remained, usually just the spire, still glued to the monofilament line.

Habitat-choice experiments. Two sets of habitatchoice experiments were conducted using newly settled conch in pairwise comparisons. The first set tested the role of Thalassia testudinum structure in habitat choice with 15 to $22 \mathrm{~mm}$ conch, and the second tested the relative importance of living $T$. testudinum, $T$. testudinum detritus, and macroalgae with 5 to $10 \mathrm{~mm}$ conch. Conch size selection was based on availability.

Treatments in the first set were bare sand, live Thalassia testudinum (125 shoots per treatment, 329 shoots $\mathrm{m}^{-2}$ ), $T$. testudinum detritus (60 $\mathrm{g}$ wet weight), and a detritus mimic $(60 \mathrm{~g})$. The mimic, made from strips of

Table 1. Thalassia testudinum. Shoot density, living biomass, and detrital biomass for 3 habitats [sand, low-density seagrass (LSG), and medium-density seagrass (MSG)] at Shark Rock (SR) and Children's Bay Cay (CBC), Bahamas, during the conch growth experiment. Values are means $\pm \mathrm{SD}_{i} \mathrm{n}=5$ for each habitat except for medium conch at SR on sand where $\mathrm{n}=6$

\begin{tabular}{|c|c|c|c|}
\hline \multirow[t]{2}{*}{ Treatment } & \multirow{2}{*}{$\begin{array}{c}\text { Shoot density } \\
\left(\text { no. } \mathrm{m}^{-2}\right)\end{array}$} & \multicolumn{2}{|c|}{ Biomass (g dry $\mathrm{m}^{-2}$ ) } \\
\hline & & Living & Detritus \\
\hline \multicolumn{4}{|l|}{ SR } \\
\hline \multicolumn{4}{|l|}{ Small conch } \\
\hline Sand & $0 \pm 0$ & $0 \pm 0$ & $0 \pm 0$ \\
\hline LSG & $220 \pm 28$ & $26.7 \pm 13.0$ & $9.6 \pm 3.9$ \\
\hline MSG & $660 \pm 42$ & $91.6 \pm 21.3$ & $120.7 \pm 34.7$ \\
\hline \multicolumn{4}{|c|}{ Medium conch } \\
\hline Sand & $0 \pm 0$ & $0 \pm 0$ & $0 \pm 0$ \\
\hline LSG & $214 \pm 16$ & $26.6 \pm 7.3$ & $16.9 \pm 8.2$ \\
\hline MSG & $584 \pm 68$ & $81.9 \pm 17.1$ & $139.8 \pm 52.2$ \\
\hline \multicolumn{4}{|c|}{ Large conch } \\
\hline Sand & $0 \pm 0$ & $0 \pm 0$ & $0 \pm 0$ \\
\hline LSG & $214 \pm 12$ & $23.1 \pm 3.2$ & $11.4 \pm 4.0$ \\
\hline MSG & $627 \pm 20$ & $48.6 \pm 5.6$ & $45.5 \pm 16.7$ \\
\hline \multicolumn{4}{|l|}{$\mathrm{CBC}$} \\
\hline \multicolumn{4}{|l|}{ Small conch } \\
\hline Sand & $0 \pm 0$ & $0 \pm 0$ & $0 \pm 0$ \\
\hline LSG & $230 \pm 44$ & $16.5 \pm 7.3$ & $11.5 \pm 4.7$ \\
\hline $\mathrm{MSG}$ & $720 \pm 91$ & $88.1 \pm 19.8$ & $181.6 \pm 78.8$ \\
\hline \multicolumn{4}{|c|}{ Medium conch } \\
\hline Sand & $0 \pm 0$ & $0 \pm 0$ & $0 \pm 0$ \\
\hline LSG & $214 \pm 18$ & $18.2 \pm 2.4$ & $9.9 \pm 2.2$ \\
\hline MSG & $578 \pm 39$ & $65.5 \pm 12.3$ & $244.4 \pm 70.2$ \\
\hline \multicolumn{4}{|l|}{ Large conch } \\
\hline Sand & $0 \pm 0$ & $0 \pm 0$ & $0 \pm 0$ \\
\hline LSG & $225 \pm 21$ & $8.0 \pm 2.6$ & $4.3 \pm 1.9$ \\
\hline MSG & $619 \pm 30$ & $55.8 \pm 7.5$ & $123.7 \pm 37.3$ \\
\hline
\end{tabular}

white, heavy bond typewriter paper resembling detritus, represented horizontal structure with no nutritional value. Juvenile conch consume detritus but little or no living $T$ testudinum (Stoner \& Waite 1991).

One treatment was placed in each half of a circular arena (diameter $0.7 \mathrm{~m}$, height $0.25 \mathrm{~m}$ ), and each comparison was replicated 4 times. Arenas were made from heavy plastic mesh material which supported a smooth vinyl sheeting liner. The bottom was made from plywood and covered with $-3 \mathrm{~cm}$ of coarse grained sand. Arenas were kept on a wet table with flow-through seawater. Ten experimental conch were measured and placed along the treatment interface. After $48 \mathrm{~h}$, treatment choice was recorded for each. Conch climbing the sides of the arena and those located along the interface were excluded from statistical analysis, and trials were repeated when fewer than 5 conch had made a distinct choice.

Treatments in the second set of habitat-choice experiments were living Thalassia testudinum (12 shoots per treatment, 423 shoots $\left.\mathrm{m}^{-2}\right)$, T. testudinum detritus $(5 \mathrm{~g}$ wet weight), and the green alga Batophora oerstedi (10 $\mathrm{g}$ wet weight). A different treatment was placed on sand in each half of a glass crystallization dish (diameter $19 \mathrm{~cm}$, depth $6.5 \mathrm{~cm}$ ) which was carefully filled with seawater. The following pairs of treatments were tested, each being replicated 4 times: living $T$. testudinum and detritus, living $T$. testudinum and $B$. oerstedi, detritus and $B$. oerstedi, and living $T$. testudinum and bare sand.

For data analysis, the proportion of conch choosing each treatment in each comparison was determined. The differences between treatments were then transformed (2 arcsin $\checkmark p$ ) and analysed with a pairedsample $t$-test as recommended by Peterson \& Renaud (1989).

\section{RESULTS}

\section{Growth experiment}

\section{Habitat characteristics}

Thalassia testudinum shoot density and living biomass data show the gradient from bare sand to medium-density seagrass, with quantities in medium seagrass at least twice those observed in low seagrass (Table 1). Detritus biomass between the 2 seagrass densities differed by at least a factor of 4 and as much as $29 \times$. Overall, detrital biomass was higher at CBC than at SR. Sediments collected outside enclosures at both sites were moderately sorted $(0.88$ to $1.10 \phi)$ medium-sized sands ( 1.47 to $1.88 \phi$ ) (Table 2 ). Organic content ranged from 2.4 to $3.6 \%$ of dry weight. 
Table 2. Sediment characteristics (organic content, grain size, and sorting) for sediments collected inside and outside cages of conch ( 3 size classes) in 3 habitats at Shark Rock (SR) and Children's Bay Cay (CBC). LSG and MSG: low-and medium-density seagrass; Outside 1: samples collected outside small and medium conch cages, which were set up earlier than the large conch cages; Outside 2: samples collected outside the large conch cages. Inside-cage grain size and sorting were only measured for small conch at SR in sand and medium-density seagrass; Student's t-test results comparing inside and outside are given. Values are means $\pm \mathrm{SD}(\mathrm{n})$

\begin{tabular}{|c|c|c|c|c|c|c|}
\hline & \multicolumn{3}{|c|}{$\longrightarrow \mathrm{SR}-{ }_{-}-{ }_{-}$} & \multicolumn{3}{|c|}{ CBC } \\
\hline & Sand & LSG & MSG & Sand & LSG & MSG \\
\hline \multicolumn{7}{|c|}{ Organic content $(\%)$} \\
\hline Outside 1 & $2.48 \pm 0.26(6)$ & $3.09 \pm 0.53(6)$ & $2.91 \pm 0.20(6)$ & $2.45 \pm 0.24(6)$ & $2.49 \pm 0.22(6)$ & $3.04 \pm 0.44(6)$ \\
\hline Outside 2 & $2.42 \pm 0.18(6)$ & $2.65 \pm 0.61(6)$ & $2.74 \pm 0.23(6)$ & $2.44 \pm 0.21(4)$ & $2.92 \pm 0.31(5)$ & $3.57 \pm 0.37(6)$ \\
\hline Small conch & $2.60 \pm 0.55(5)$ & $2.80 \pm 0.27(5)$ & $2.99 \pm 0.30(5)$ & $2.25 \pm 0.25(6)$ & $2.52 \pm 0.38(5)$ & $3.27 \pm 0.34(5)$ \\
\hline Med. conch & $2.30 \pm 0.28(6)$ & $2.72 \pm 0.28(5)$ & $3.00 \pm 0.49(5)$ & $2.30 \pm 0.15(5)$ & $2.68 \pm 0.14(5)$ & $4.49 \pm 1.74(5)$ \\
\hline Large conch & $2.30 \pm 0.25(5)$ & $2.45 \pm 0.23(5)$ & $2.42 \pm 0.30(5)$ & $2.32 \pm 0.40(5)$ & $2.42 \pm 0.26(5)$ & $3.40 \pm 0.57(5)$ \\
\hline \multicolumn{7}{|l|}{ Grain size $(\phi)$} \\
\hline Outside 1 & $1.88 \pm 0.09(3)$ & $1.88 \pm 0.02(2)$ & $1.69 \pm 0.20(3)$ & $1.47 \pm 0.09(2)$ & $1.52 \pm 0.04(2)$ & $1.62 \pm 0.02(2)$ \\
\hline Small conch & $\begin{array}{c}1.92 \pm 0.10(3) \\
t_{(4)}=-0.53 \\
p=0.63\end{array}$ & & $\begin{aligned} 1.85 & \pm 0.14(3) \\
t_{(4)} & =-1.16 \\
p & =0.31\end{aligned}$ & & & \\
\hline \multicolumn{7}{|l|}{ Sorting $(\phi)$} \\
\hline Outside 1 & $0.96 \pm 0.12(3)$ & $0.97 \pm 0.05(2)$ & $1.10 \pm 0.20(3)$ & $0.88 \pm 0.05(2)$ & $0.96 \pm 0.05(2)$ & $0.97 \pm 0.12$ \\
\hline Small conch & $\begin{aligned} 0.75 & \pm 0.12 \\
t_{[4]} & =2.16 \\
p & =0.10\end{aligned}$ & & $\begin{aligned} 0.96 & \pm 0.18(3) \\
t_{(4)} & =0.91 \\
p & =0.41\end{aligned}$ & & & \\
\hline
\end{tabular}

\section{Cage effects}

We had predicted that if cage effects on sediment characteristics occurred, they would most likely be observed in smaller cages in extreme habitats. When samples collected from outside the small conch cages in sand and from medium-density seagrass at SR were compared with samples from inside small conch cages, there were no significant cage effects in terms of sediment sorting or grain size (Table 2).

To test for cage effects in sediment organics (Table 2), 2-way ANOVA was run for each site and conch size, with habitat (sand, low seagrass, medium seagrass) and type (inside cage, outside cage) as independent variables. There were no significant interactions between habitat and type, and no significant differences between types. Differences among the 3 habitats were always significant ( $p<0.03$ ), except for large-conch enclosures at SR $(p=0.26)$, and organics tended to increase from sand to medium-density seagrass. Lack of any cage effects in measured sediment characteristics confirms the usefulness of caging as a technique for testing habitat suitability.

\section{Growth}

Results of 2-way ANOVA on growth rates of small and medium conch showed significant habitat effects but no site effects or site $\times$ habitat interactions
(Table 3). Therefore, rates for both sites were pooled. Small conch growth was significantly higher in lowdensity seagrass $\left(0.306 \mathrm{~mm} \mathrm{~d}^{-1}\right)$ than in medium seagrass $\left(0.272 \mathrm{~mm} \mathrm{~d}^{-1}\right)$, but growth on sand $(0.285 \mathrm{~mm}$ $\mathrm{d}^{-1}$ ) was not different from either seagrass habitat (Fig. 2). Medium conch growth, however, was lowest on sand $\left(0.395 \mathrm{~mm} \mathrm{~d}^{-1}\right)$, and there was no difference between the seagrass habitats. Because there was a

Table 3. Strombus gigas. Results of 2-way ANOVA considering growth as a function of site and habitat for 3 conch size classes. Data for small conch were transformed $\left(\log _{10}\right)$ to improve homogeneity of variance

\begin{tabular}{|c|c|c|c|c|}
\hline & $\mathrm{df}$ & MS & $F$ & $\mathrm{p}$ \\
\hline \multicolumn{5}{|l|}{ Small conch } \\
\hline Site & 1 & 0.001 & 1.000 & 0.327 \\
\hline Habitat & 2 & 0.007 & 4.983 & 0.015 \\
\hline Site $\times$ habitat & 2 & $<0.001$ & 0.354 & 0.705 \\
\hline Error & 24 & 0.001 & & \\
\hline \multicolumn{5}{|l|}{ Medium conch } \\
\hline Site & 1 & $<0.001$ & 0.236 & 0.632 \\
\hline Habitat & 2 & 0.039 & 19.72 & $<0.001$ \\
\hline Site $\times$ habitat & 2 & 0.001 & 0.277 & 0.760 \\
\hline Error & 25 & 0.002 & & \\
\hline \multicolumn{5}{|l|}{ Large conch } \\
\hline Site & 1 & 0.004 & 5.598 & 0.026 \\
\hline Habitat & 2 & 0.040 & 51.84 & $<0.001$ \\
\hline Site $\times$ habitat & 2 & 0.001 & 1.304 & 0.290 \\
\hline Error & 24 & 0.001 & & \\
\hline
\end{tabular}



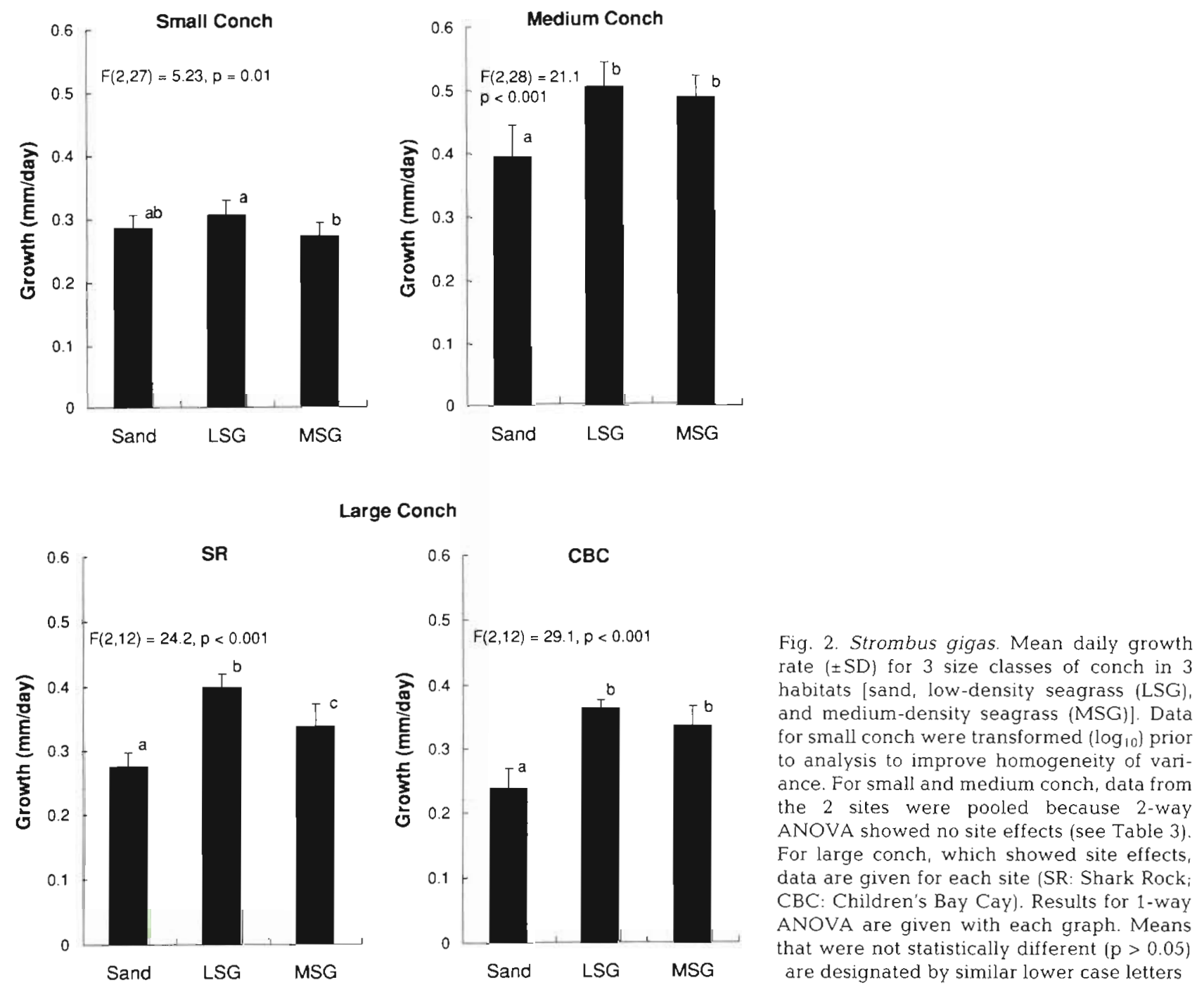

significant site difference for large conch (Table 3), each site was analysed separately. In both cases conch growth was lowest on bare sand (Fig. 2). Also, growth in low-density seagrass tended to be higher than growth in medium seagrass, but the difference was significant only at SR.

Linear regressions considering total animal weight as a function of shell length were usually positive and significant (Fig. 3A, B). There were no significant differences among habitats for large conch at either site when the effects of the covariate shell length were removed by ANCOVA. However, at both sites, small conch on sand weighed more than small conch in medium-density seagrass; weights in both densities of seagrass were similar. Medium conch on sand also weighed more than medium conch in medium seagrass, but they weighed more in low seagrass than in medium seagrass. Habitat effect on the weight-length ratio decreased with increasing conch size.
When growth for each size class at each site was considered as a linear function of detritus collected from the cages, correlations were poor and none of the regressions were significant [Pearson correlation coefficient $(R) \leq 0.483, p>0.05$ in all 6 cases].

\section{Tether experiment}

Thalassia testudinum shoot density in mediumdensity seagrass was $5 \times$ that observed in low-density seagrass at $\mathrm{SR}$ and $3 \times$ that at CBC (Table 4 ). Living $T$. testudinum and detrital biomass were at least $4 \times$ higher in medium-density seagrass. The green alga Batophora oerstedi was collected only at SR from quadrats in low-density seagrass $\left(3.49 \pm 5.6 \mathrm{~g} \mathrm{~m}^{-2}\right)$ and from sand $\left(5.66 \pm 11.62 \mathrm{~g} \mathrm{~m}^{-2}\right)$.

Conch tethered on sand were usually observed nestled in the sand with their dorsal spines exposed, 


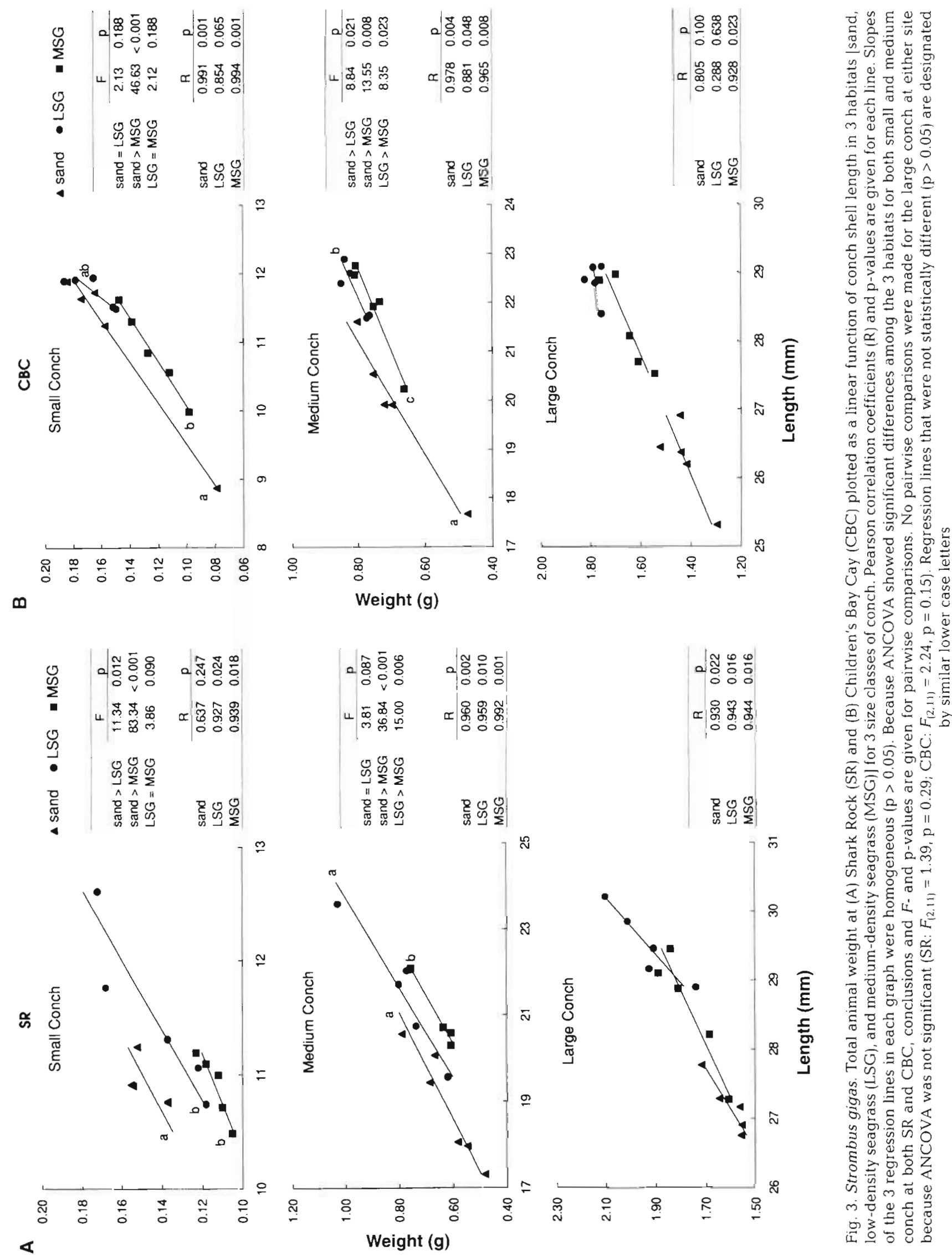


Table 4. Thalassia testudinum. Shoot density, living biomass, and detrital biomass for 3 habitats [sand, low-density seagrass (LSG), and medium-density seagrass (MSG)] at Shark Rock (SR) and Children's Bay Cay (CBC) for the tether experiment.

Depth is at mean low water. Values are mean $\pm S D(n=5)$

\begin{tabular}{|lcccc|}
\hline & $\begin{array}{c}\text { Depth } \\
(\mathrm{m})\end{array}$ & $\begin{array}{c}\text { Shoot density } \\
\left(\text { no. } \mathrm{m}^{-2}\right)\end{array}$ & \multicolumn{2}{c|}{ Biomass $\left(\mathrm{g} \mathrm{m}^{-2}\right)$} \\
Living & Detritus \\
\hline SR & & & & \\
Sand & 1.7 & $0 \pm 0$ & $0 \pm 0$ & $0 \pm 0$ \\
LSG & 1.6 & $147 \pm 97$ & $14.1 \pm 12.7$ & $2.7 \pm 2.5$ \\
MSG & 2.4 & $730 \pm 220$ & $58.0 \pm 12.9$ & $29.7 \pm 29.8$ \\
CBC & & & & \\
Sand & 1.1 & $0 \pm 0$ & $0 \pm 0$ & $0 \pm 0$ \\
LSG & 1.0 & $173 \pm 89$ & $4.1 \pm 1.6$ & $0 \pm 0$ \\
MSG & 2.9 & $515 \pm 113$ & $46.7 \pm 16.4$ & $51.4 \pm 47.8$ \\
\hline
\end{tabular}

\section{Habitat choice experiments}

In the first set of experiments, conch (15 to $22 \mathrm{~mm}$ ) chose horizontal structure (detritus and the detritus mimic) over bare sand and living Thalassia testudinum, but the difference in preference for the vertical structure provided by living $T$. testudinum over bare sand was not significant (Table 6). The detritus mimic made from paper was apparently an effective substitute, and no preference was shown for real detritus.

In the second set of experiments, smaller animals (5 to $10 \mathrm{~mm}$ ) preferred living Thalassia testudinum over bare sand and the green alga Batophora oerstedi over both detritus and living $T$. testudinum, but showed no significant preference for detritus over living $T$. testudinum (Table 7 ). secure enough to avoid being swept away in the current but not completely buried. In seagrass they nestled under detritus and at the base of blades but not in the sediment.

At $\mathrm{CBC}$, cumulative conch mortality was significantly higher on low-density seagrass than on medium-density seagrass from Day 6 through Day 26 (1-way ANOVA, $p \leq 0.04$ for all cases, followed by Tukey test, $p \leq 0.03$ ) (Fig. 4). Mortality on bare sand was always lower than in low-density seagrass and higher than in medium-density seagrass, but differences were not significant ( $p>0.15)$. At SR, mortality curves for sand and lowdensity seagrass overlapped. Again, lowest mortality was observed in medium-density seagrass, though differences were not significant on any day (1-way ANOVA, $p \geq 0.15$ for all cases)

Of the tethered conch that were killed and whose shells remained on tethers, at least $50 \%$ of those on sand and in mediumdensity seagrass at both sites were crushed (Table 5). Most (48 to $56 \%$ ) of the shells of killed conch remaining in low-density seagrass were undamaged. A total of 10 tethered conch from the 2 sites in sand and low-density seagrass were found in stomachs of seastar Astropecten duplicatus still attached to tethers. No seastar predation was observed in medium-density seagrass. This predator leaves shells intact and was probably responsible for at least some of the deaths of conch whose shells were not damaged. Few conch $(\leq 3 \%)$ were peeled, and 15 to $30 \%$ had less severe aperture damages.

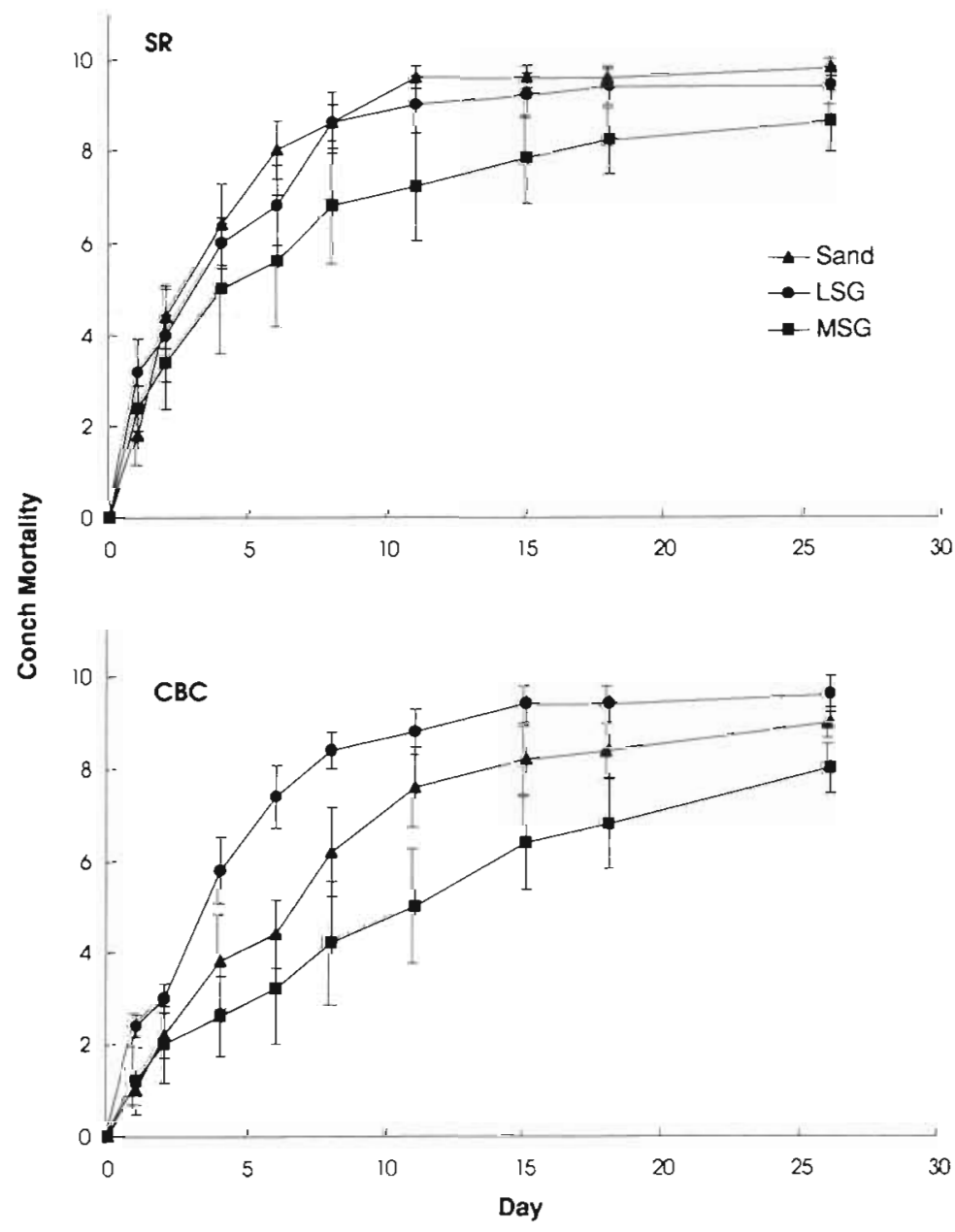

Fig. 4. Strombus gigas. Cumulative number of tethered conch killed per block of 10 (mean $\pm \mathrm{SE}$ ) in 3 habitats (sand, low-density seagrass (LSG), and medium-density seagrass (MSG)] at Shark Rock (SR) and Children's Bay Cay $(\mathrm{CBC})$ 
Table 5. Strombus gigas. Shell condition of killed conch at Shark Rock (SR) and Children's Bay Cay (CBC) as noted on the first observation day after mortality. Values are the number of killed conch remaining on tethers which showed different types of shell damage or which were found in the stomachs of Astropecten duplicatus (percentage given in parantheses). See 'Methods' for category definitions. The number of conch killed out of 50 as well as the number of shells separated completely from their tethers and considered killed are also given

\begin{tabular}{|c|c|c|c|c|c|c|}
\hline & \multicolumn{3}{|c|}{$-\mathrm{SR}$} & \multicolumn{2}{|r|}{$-\mathrm{CBC}$} & \multirow[b]{2}{*}{$\mathrm{MSG}$} \\
\hline & Sand & LSG & MSG & Sand & LSG & \\
\hline A. duplicatus & $2(6)$ & $1(2)$ & $0(0)$ & $3(8)$ & $4(10)$ & $0(0)$ \\
\hline No shell damage & $2(6)$ & $23(56)$ & $2(10)$ & $7(19)$ & $20(48)$ & $4(15)$ \\
\hline Aperture damage & $5(15)$ & $9(22)$ & $7(33)$ & $7(19)$ & $12(29)$ & $8(30)$ \\
\hline Peel & $1(3)$ & $0(0)$ & $0(0)$ & $1(3)$ & $1(2)$ & $0(0)$ \\
\hline Crushed & $23(70)$ & $8(20)$ & $12(57)$ & $18(50)$ & $5(12)$ & $15(56)$ \\
\hline No. of shells gone & 16 & 6 & 22 & 9 & 6 & 13 \\
\hline No. of dead conch & 49 & 47 & 43 & 45 & 48 & 40 \\
\hline
\end{tabular}

Table 6. Strombus gigas. Preferences shown by newly settled conch (15 to $22 \mathrm{~mm}$ ) during 5 habitat choice comparisons. Treatments were live Thalassia testudinum, detritus, a detritus mimic (see 'Methods'), and bare sand. Direction of choice is based on results from paired-sample $t$-tests $\left({ }^{\mathrm{ns}} \mathrm{p}>0.05\right.$ $\cdots p<0.01)_{;}(n)$ is the total number of conch in 4 replicates that chose the treatment

\begin{tabular}{|ll|}
\hline Choice & Result \\
\hline T. testudinum $(22)=$ sand $(10)$ & $t_{(3)}=1.45^{\mathrm{ns}}$ \\
Detritus $(29)>$ sand $(1)$ & $t_{(3)}=9.21 \cdots$ \\
Detritus $(34)>T$ testudinum $(4)$ & $t_{13\}}=5.96 \cdots$ \\
Detritus $(15)=$ mimic $(22)$ & $t_{(3)}=0.80^{\mathrm{ns}}$ \\
Mimic $(22)>$ sand $(10)$ & $t_{\{3\}}=9.60^{\cdots}$ \\
\hline
\end{tabular}

\section{DISCUSSION}

In this study, the roles of predation, nutrition, and habitat choice were tested as mechanisms for shaping natural distribution of newly settled queen conch. Juveniles under 1 yr old $(<55 \mathrm{~mm})$ are rarely found in the wild, and very little is known about them. Results from previous transplant and growth experiments showed bare sand habitat to be nutritionally poor for conch larger than those studied herein ( 37 to $49 \mathrm{~mm}$, Sandt \& Stoner 1993; 95 to $109 \mathrm{~mm}$, Ray \& Stoner 1994). Conch from our medium and large size classes (9 to $24 \mathrm{~mm}$ ) also grew slowest when enclosed on bare sand habitat, while small conch $(5 \mathrm{~mm})$ grew as fast on sand as those in both densities of seagrass.

If they settled on sand at the 2 study sites, small animals would probably be able to derive sufficient nutrition by feeding only on the benthic diatoms and cyanobacteria that were abundant there. Even our medium and large conch grew well on sand $(0.2$ to $0.5 \mathrm{~mm} \mathrm{~d}^{-1}$, within and above the range reported for cultured animals $\left(0.1\right.$ to $0.4 \mathrm{~mm} \mathrm{~d}^{-1}$; Brownell 1977 , Ballantine \& Appeldoorn 1983, Davis \& Dalton 1991)
Table 7. Strombus gigas. Preferences shown by newly settled conch ( 5 to $10 \mathrm{~mm}$ ) during 4 habitat choice comparisons. Treatments were live Thalassia testudinum, detritus, the green macroalga Batophora oerstedi, and bare sand. Direction of choice is based on results from paired-sample $t$-tests $\left({ }^{\mathrm{ns}} \mathrm{p}>0.05 ; \cdot \mathrm{p}<0.05 ; \cdots p<0.01\right) ;(\mathrm{n})$ is the total number of conch in 4 or 5 replicates that chose the treatment

\begin{tabular}{ll} 
Choice & Result \\
\hline$T$ testudinum $(27)>$ sand $(6)$ & $t_{(3)}=4.60^{\circ}$ \\
Detritus $(18)=T$ testudinum $(11)$ & $t_{(3)}=0.93^{\mathrm{ns}}$ \\
B. oerstedi $(37)>T$ testudinum $(3)$ & $t_{(3)}=10.6^{\cdots}$ \\
B. oerstedi $(39)>$ detritus $(10)$ & $t_{(4)}=4.96^{\cdots}$ \\
\hline
\end{tabular}

even though rates were significantly lower than in seagrass. Consumption of foods with higher biomass such as detritus, macroalgae, and epiphytes (Stoner \& Waite 1991, Stoner et al. 1995b) apparently becomes more important with size. Large conch may have grown better at SR in low-density seagrass than in medium seagrass because there was more Batophora oerstedi in low seagrass. This green macroalga appears to be an important food item (Stoner \& Waite 1991), and habitat-choice experiments showed conch preferred it.

In this study, the 2 different indices used to assess nutrition and suitable habitat, daily growth rate in shell length and the ratio of length to weight, gave different results. For the same shell length, small and medium conch weights were higher on sand than in mediumdensity seagrass, even though growth rates were low on sand. Conch in different habitats are known to express different morphologies as a result of differential growth rates and foods (Alcolado 1976, MartínMora et al. 1995). It is possible that this occurs on a small scale, particularly with small conch which probably do not cross habitats often. 
All but 8 of the experimental conch recovered from their protective enclosures were alive, while nearly all tethered conch were killed. This suggests that nonpredator induced mortality was low and, regardless of habitat, experimental animals did not die from starvation. Appropriate habitat must be defined in terms of available shelter and protection from predation as well as nutritional requirements. Many invertebrates exhibit the ability to choose habitats in which predation is relatively low (Leber 1985, Bell \& Westoby 1986, Fernandez et al. 1993). Older juvenile conch are usually found in medium-density seagrass (608 to 864 shoots $\mathrm{m}^{-2}$ ) and are capable of choosing this density over high or low density (Stoner \& Waite 1990), but no correlation was observed between Thalassia testudinum density and conch growth rate (Ray \& Stoner 1994). In all of our preference experiments, more conch chose the structure provided by $T$. testudinum, detritus, and the detritus mimic over bare sand. Furthermore, mortality was lowest in medium-density seagrass. Behavioral preference for vegetative structure is probably an evolutionary adaptation to both predation pressure and nutritional adequacy of habitat. In this study, however, food was not limiting and predation was the significant cause of mortality.

Suspected or known conch predators include brachyuran crabs, hermit crabs, other gastropods, spiny lobster, octopus, fish, sharks, rays, and sea turtles (Randall 1964). Crustacean predators tend to crush, chip, or peel conch shells, vertebrates tend to crush them, and the gastropods Fasciolaria tulipa (tulip snail) and Murex pomum (apple murex) leave shells intact (Randall 1964, Bertness \& Cunningham 1981, Vermeij 1982, 1987. Iversen et al. 1986, Davis 1992). The seastar Astropecten duplicatus also leaves shells intact, and predation on conch by this species has not been previously reported. Most species of Astropecten feed mainly on small molluscs, digest intraorally, eject undigestible parts undamaged, and, to varying degrees, sense their prey chemically /Christensen 1970, Ribi \& Jost 1978, Sloan 1980, Beddingfield \& McClintock 1993).

In this study, most tethered conch were crushed. Shells become harder to crush as conch increase in shell length because, beyond $55 \mathrm{~mm}$, small increases in length yield rapid increases in shell strength (Jory \& Iversen 1988). Death by crushing decreases with size, and conch appear to achieve an effective size refuge at $90 \mathrm{~mm}$ (Davis 1992, Ray et al. 1994). The Caribbean seastar Astropecten articulatus is known to prefer smaller-sized prey (Beddingfield \& McClintock 1993), and many molluscs escape predator-induced mortality as they age and grow larger (Bertness \& Cunningham 1981, Vermeij 1987, Palmer 1990. Juanes 1992).
Although ontogenetic shifts in habitat frequently occur in animals (Werner \& Hall 1988, Wahle \& Steneck 1992, Rayor \& Uetz 1993), the results of this study suggest that there may be no opportunity for habitat shift to occur because conch settling on sand may be preyed upon long before food becomes limiting. Early juvenile conch discovered by Sandt \& Stoner (1993) on bare sand at Neighbor Cay (Fig. 1) may have been an unusual occurrence. They predicted that nutrition would become limiting and an ontogenetic shift into seagrass would occur. In fact, more than $50 \%$ of their study population was killed in a few days. Early postsettlement, predation-induced mortality is also high in fish (Williams 1980, Shulman \& Ogden 1987) and many other marine invertebrates (Keough \& Downes 1982, Hurlbut 1991).

Frequently, animal abundance in seagrass beds is correlated with habitat complexity measured in terms of seagrass blade density or biomass, detrital biomass, leaf characteristics, or rhizome structure (Orth et al. 1984, Stoner \& Lewis 1985, Edgar \& Robertson 1992). This correlation has also been observed in nurseries for juvenile conch older than 1 yr (Stoner \& Waite 1990). Dead, newly settled conch were found in dredge samples collected at SR at locations across the seagrass gradient from bare sand to high density seagrass, but live ones were recovered only from the seagrass habitats (Stoner unpubl. data). These findings indicate that larvae settled in all habitats, but those which settled on sand were all killed soon after settlement. Even in the seagrass habitats, $\leq 40 \%$ of recoveries were live. Results from the present study corroborate the dredge findings -50 to $90 \%$ of the conch tethered in the 2 seagrass habitats and 76 to $96 \%$ tethered on sand were killed in $11 \mathrm{~d}$. Mortality of newly settled conch is apparently very high regardless of habitat, but individuals living in medium seagrass have an advantage Predation strongly influences observed distribution patterns within a nursery.

Large-scale distribution is probably affected by other mechanisms. Relatively similar seagrass habitats can show large differences in macrofauna abundance and composition (Brook 1978). Seagrass and detritus differ qualitatively among locations, and seemingly similar habitats produce differential conch growth rates (Stoner \& Sandt 1991, Stoner et al. 1994). Dredge samples collected east and west of SR, outside the general nursery area, showed little sign of settlement despite the availability of larvae (Stoner et al. 1994, Stoner unpubl. data). Apparently, over large scale, larvae settle selectively into general areas conducive to juvenile growth (Davis \& Stoner 1994). Within the confines of those general areas, they settle at all locations across the seagrass gradient. Mortality rates of tethered conch were high in all locations, but highest sur- 
vivorship occurred in medium-density seagrass. If larvae settle on sand, nutrition is adequate but chances of survival are exceptionally poor. Although the ability to choose habitat providing nutrition and vegetative shelter influences observed distribution patterns of older juveniles, predation appears to be the most important mechanism in newly settled conch.

The queen conch has been severely overfished throughout its range (Berg \& Olsen 1989), and the release of hatchery-reared animals to rehabilitate depleted stocks was first proposed nearly 20 years ago (Berg 1976). Determining habitat suitability in terms of growth and mortality is a crucial first step before large-scale release of conch is attempted (Stoner 1994). Furthermore, it is important to test each size class that will be outplanted because habitat requirements may change with age. Caging and tethering are relatively easy techniques with which to evaluate and compare potential habitats in terms of nutrition and predation.

Acknowledgements. We thank M. Davis, L. Hambrick, R. Jones, C. Kelso, S. O'Connell, and V. Sandt for their help in the field and lab. M. Davis, N. Mehta, S. O'Connell, and 2 anonymous reviewers commented on the manuscript. Funding for this research was provided by a grant from the National Undersea Research Program, NOAA, U.S. Dept of Commerce.

\section{LITERATURE CITED}

Alcolado PM (1976) Crecimiento, variaciones morfologicas de la concha y algunas datos biologicos del cobo Strombus gigas L. (Mollusca, Mesogastropoda). Acad Cien Cuba Ser Oceanol 34:1-36

Appeldoorn RS (1988) Ontogenetic changes in natural mortality rate of queen conch, Strombus gigas (Mollusca: Mesogastropoda). Bull mar Sci 42:159-165

Ballantine DL, Appeldoorn RS (1983) Queen conch culture and future prospects in Puerto Rico. Proc Gulf Caribb Fish Inst 35:57-63

Beddingfield SD, McClintock JB (1993) Feeding behavior of the sea star Astropecten articulatus (Echinodermata: Asteroidea): an evaluation of energy-efficient foraging in a soft-bottom predator. Mar Biol 115:669-676

Bell JD, Steffe AS, Westoby M (1988) Location of seagrass beds in estuaries: effects on associated fish and decapods. J exp mar Biol Ecol 122:127-146

Bell JD, Westoby $M$ (1986) Abundance of macrofauna in dense seagrass is due to habitat preference, not predation. Oecologia 68:205-209

Berg DJ Jr (1976) Growth of the queen conch Strombus gigas, with a discussion of the practicality of its mariculture. Mar Biol 4:191-199

Berg DJ Jr, Olsen DA (1989) Conservation and managment of queen conch (Strombus gigas) fisheries in the Caribbean. In: Caddy JF (ed) Marine invertebrate fisheries: their assessment and management. J Wiley and Sons, Inc, New York, p 421-442

Bertness MD, Cunningham C (1981) Crab shell-crushing predation and gastropod architectural defense. J exp mar Biol Ecol 50:213-230
Brook IM (1978) Comparative macrofaunal abundance in turtlegrass (Thalassia testudinum) communities in south Florida characterized by high blade density. Bull mar Sci 28:212-217

Brownell WN (1977) Reproduction, laboratory culture, and growth of Strombus gigas, S. costatus and S. Pugilus in Los Roques, Venezuela. Bull mar Sci 27:668-680

Christensen AM (1970) Feeding biology of the sea-star Astropecten irregularis Pennant. Ophelia 8:1-134

Davis M (1992) Predation of hatchery-reared juvenile queen conch, Strombus gigas (L.) by juvenile spiny lobsters, Panulirus argus (L.). MSc thesis, Florida Inst of Technology, Melbourne

Davis M, Dalton A (1991) New large-scale culturing techniques for Strombus gigas post larvae in the Turks and Caicos Islands. Proc Gulf Caribb Fish Inst 40:257-266

Davis M, Stoner AW (1994) Trophic cues induce metamorphosis of queen conch larvae (Strombus gigas Linnaeus) J exp mar Biol Ecol 180:83-102

Day RW, Quinn GP (1989) Comparisons of treatments after an analysis of variance in ecology. Ecol Monogr 59:433-463

Edgar GJ, Robertson AI (1992) The influence of seagrass structure on the distribution and abundance of mobile epifauna: pattern and process in a Western Australian amphibolis bed. J exp mar Biol Ecol 160:13-31

Fernandez M, Iribarne O, Armstrong D (1993) Habitat selection by young-of-the-year Dungeness crab Cancer magister and predation risk in intertidal habitats. Mar Ecol Prog Ser 92:171-177

Folk RL (1966) A review of grain-size parameters. Sedimentology 6:73-93

Heck KL Jr, Able KW, Fahay MP, Roman CT (1989) Fishes and decapod crustaceans of Cape Cod eelgrass meadows: species composition, seasonal abundance patterns and comparison with unvegetated substrates. Estuaries 12:59-65

Heck KL Jr, Thoman TA (1981) Experiments on predator-prey interactions in vegetated aquatic habitats. $J$ exp mar Biol Ecol 53:125-134

Heck KL Jr, Wilson KA (1987) Predation rates on decapod crustaceans in latitudinally separated seagrass communities: a study of spatial and temporal variation using tethering techniques. J exp mar Biol Ecol 107:87-100

Howard RK, Edgar GJ, Hutchings PA (1989) Faunal assemblages of seagrass beds. In: Larkum AWD, McComb AJ, Shepherd SA (eds) Biology of seagrasses II. Elsevier, Amsterdam, p 536-564

Hurlbut CJ (1991) Community recruitment: settlement and juvenile survival of seven co-occuring species of sessile marine invertebrates. Mar Biol 109:507-515

Irlandi EA (1994) Large- and small-scale effects of habitat structure on rates of predation: how percent coverage of seagrass affects rates of predation and siphon nipping on an infaunal bivalve. Oecologia 98:176-183

Iverson ES, Jory DE, Bannerot SP (1986) Predation on queen conchs, Strombus gigas, in the Bahamas. Bull mar Sci 39: $61-75$

Jory DE, Iversen ES (1988) Shell strength of queen conch, Strombus gigas L.. aquaculture implications. Aquacult Fish Mgmt 19:45-51

Juanes $F$ (1992) Why do decapod crustaceans prefer smallsized molluscan prey? Mar Ecol Prog Ser 87:239-249

Keough MJ, Downes BJ (1982) Recruitment of marine invertebrates: the role of active larval choices and early mortality. Oecologia 54:348-352

Leber KM (1985) The influence of predatory decapods, refuge, and microhabitat selection on seagrass communities. Ecology 66:1951-1964 
Livingston RJ (1984) Trophic response of fishes to habitat variability in coastal seagrass systems. Ecology 65:1258-1275

Marshall LS (1992) Survival of juvenile queen conch, Strombus gigas, in natural habitats: impact of prey, predator and habitat features. PhD dissertation, College of William and Mary, Williamsburg, VA

Martín-Mora E, James FC, Stoner AW (1995) Developmental plasticity in the shell of the queen conch Strombus gigas. Ecology 76:981-994

McBride EF (1971) Mathematical treatment of size distribution data. In: Carver RE (ed) Procedures in sedimentary petrology. Wiley, New York, p 109-127

Orth RJ (1992) A perspective on plant-animal interactions in seagrasses: physical and biological determinants influencing plant and animal abundance. In: John DM, Hawkins $\mathrm{SJ}$, Price $\mathrm{JH}$ (eds) Plant-animal interactions in the marine benthos. Systematics Association Spec Vol 46. Clarendon Press, Oxford, p 147-164

Orth RJ, Heck Jr KL, van Montfrans J (1984) Faunal communities in seagrass beds: a review of the influence of plant structure and prey characteristics on predator-prey relationships. Estuaries 7:339-350

Palmer AR (1990) Predator size, prey size, and the scaling of vulnerability: hatchling gastropods vs. barnacles. Ecology 71:759-775

Peterson $\mathrm{CH}_{1}$ Renaud PE (1989) Analysis of feeding preference experiments. Oecologia 80:82-86

Pettersson LB, Bronmark C (1993) Trading off safety against food: state dependent habitat choice and foraging in crucian carp. Oecologia 95:353-357

Randall JE (1964) Contributions to the biology of the queen conch, Strombus gigas. Bull mar Sci Gulf Caribb 14: 246-295

Ray M, Stoner AW (1994) Experimental analysis of growth and survivorship in a marine gastropod aggregation: balancing growth with safety in numbers. Mar Ecol Prog Ser 105:47-59

Ray M, Stoner AW, O'Connell SM (1994) Size-specific predation of juvenile queen conch Strombus gigas: implications for stock enhancement. Aquaculture 128:79-88

Rayor LS, Uetz GW (1993) Ontogenetic shifts within the selfish herd: predation risk and foraging trade-offs with age in colonial web-building spiders. Oecologia 95:1-8

Ribi G, Jost P (1978) Feeding rate and duration of daily activity of Astropecten aranciacus (Echinodermata: Asteroidea) in relation to prey density. Mar Biol 45:249-254

Sandt VJ, Stoner AW (1993) Ontogenetic shift in habitat by early juvenile queen conch, Strombus gigas: patterns and potential mechanisms. Fish Bull US 91:516-525

Shulman MJ, Ogden JC (1987) What controls tropical reef fish populations: recruitment or benthic mortality? An example in the Caribbean reef fish Haemulon flavolineatum. Mar Ecol Prog Ser 39:233-242

Sloan NA (1980) Aspects of the feeding biology of asteroids Oceanogr mar Biol A Rev 18:57-124

Smith KN, Herrnkind WF (1992) Predation on early juvenile spiny lobsters Panularus argus (Latreille): influence of size and shelter. J exp mar Biol Ecol 157:3-18

Stoner AW (1983) Distribution of fishes in seagrass meadows: role of macrophyte biomass and species composition. Fish Bull US 81:837-846

Stoner AW (1994) Significance of habitat and stock pre-testing for enhancement of natural fisheries: experimental analyses with queen conch Strombus gigas. J World

This article was submitted to the editor
Aquacult Soc 25:155-165

Stoner AW, Hanisak MD, Smith NP, Armstrong RA (1994) Large-scale distribution of queen conch nursery habitats: implications for stock enhancement. In: Appeldoorn RS, Rodriguez B (eds) Queen conch biology, fisheries and mariculture. Fundación Científica Los Roques, Caracas, Venezuela, p 169-189

Stoner AW, Lewis FG III (1985) The influence of quantitative and qualitative aspects of habitat complexity in tropical sea-grass meadows. J exp mar Biol Ecol 94:19-40

Stoner AW, Pitts PA, Armstrong RA (1995a) The interaction of physical and biological factors in the large-scale distribution of juvenile queen conch in seagrass meadows. Bull mar Sci (in press)

Stoner AW, Ray M (1993) Aggregation dynamics in juvenile queen conch: population structure, mortality, growth, and migration. Mar Biol 116:571-582

Stoner AW, Ray M, Waite JM (1995b) Effects of a large herbivorous gastropod on macrofauna communities in tropical seagrass meadows. Mar Ecol Prog Ser 121: 125-137

Stoner AW, Sandt VJ (1991) Experimental analysis of habitat quality for juvenile queen conch in seagrass meadows Fish Bull US 89:693-700

Stoner AW, Schwarte KC (1994) Queen conch, Strombus gigas, reproductive stocks in the central Bahamas: distribution and probable sources. Fish Bull US 92:171-179

Stoner AW, Waite JM (1990) Distribution and behavior of queen conch, Strombus gigas, relative to seagrass standing crop. Fish Bull US 88:573-585

Stoner AW, Waite JM (1991) Trophic biology of Strombus gigas in nursery habitats: diets and food sources in seagrass meadows. J mollusc Stud 57:451-460

Vermeij GJ (1982) Gastropod shell form, breakage, and repair in relation to predation by the crab Calappa. Malacologia $23: 1-12$

Vermeij GJ (1987) Evolution and escalation: an ecological history of life. Princeton Univ Press, Princeton, NJ

Wahle RA, Steneck RS (1992) Habitat restrictions in early benthic life: experiments on habitat selection and in situ predation with the American lobster. J exp mar Biol Ecol 157:91-114

Weil ME, Laughlin R (1984) Biology, population dynamics, and reproduction of the queen conch, Strombus gigas Linne, in the Archipielago de Los Roques National Park. J Shellfish Res 4:45-62

Werner EE, Hall DJ (1988) Ontogenetic habitat shifts in bluegill: the foraging rate - predation risk trade-off. Ecology 69:1352-1366

Wicklund Rl, Hepp LJ, Wenz GA (1991) Preliminary studies on the early life history of the queen conch, Strombus gigas, in the Exuma Cays, Bahamas. Proc Gulf Caribb Fish Inst 40:283-298

Williams D McB (1980) Dynamics of the pomacentrid community on small patch reefs in One Tree Lagoon (Great Barrier Reef). Bull mar Sci 30:159-170

Wilson KA, Able KW, Heck KL Jr (1990) Predation rates on juvenile blue crabs in estuarine nursery habitats: evidence for the importance of macroalgae (Ulva lactuca). Mar Ecol Prog Ser 58:243-251

Woodbury BD (1986) The role of growth, predation, and habitat selection in the population distribution of the crown conch, Melongena corona Gmelin. J exp mar Biol Ecol 97: $1-12$

Manuscript first received: November 15, 1994

Revised version accepted: March 2, 1995 